\title{
Komunikasi KPU dalam Menekan Golput di Jember
}

\author{
Ferdian Ardani Putram, Ahmad Fauzi \\ Universitas Islam Jember \\ ferdianardiani@gmail.com
}

\begin{abstract}
Indonesia is a country that applies a democratic political system. One of the means of the democratic political system in Indonesia is the General Election. The implementation of a democratic election should be carried out in accordance with the election principles abided by Indonesia, namely Luber-Jurdil (Direct, General, Free, Confidential, Honest, Fair). In order for the principle of Luber-Jurdil to be carried out, supervisions are requireds. Supervision is not only carried out by Panwaslu (General Election Supervisory Agency), the public also have to play a role in that supervision. The public can monitor, either directly or indirectly, the process of running a democracy / elections. The results of the current study show that there were several causes of abstention in the last 2018 elections, namely: 1) Internal factors which include technical factor and occupational factor, 2). External factors which include administrative factor, and political factor. There are also solutions to reduce the number of abstentions for the next election by easing the rules for voters to be able to vote, improving the data collection and voter registration system so that it has fresher outlook (requires adequate personnel and budget support), changing the right to vote into an obligation to vote. The electoral system must be very easy for voters to understand (for example, easy voting procedures, simple ballot paper design). For those solutions, it is necessary to involve strategic groups, such as first-time voters, religious people, women, people with disabilities and marginalized groups.
\end{abstract}

Keywords: Communication, Election, Abstention

\section{Abstrak}

Indonesia merupakan negara yang menerapkan sistem politik demokrasi. Salah satu sarana sistem politik demokrasi di Indonesia adalah Pemilihan Umum. Penyelenggaraan pemilu yang demokratis harus dilaksanakan sesuai dengan prinsip pemilu yang dianut Indonesia, yaitu Luber-Jurdil (Langsung, Umum, Bebas, Rahasia, Jujur, Adil). Agar asas Luber-Jurdil dapat dijalankan, diperlukan pengawasan. Pengawasan tidak hanya dilakukan oleh Panwaslu, masyarakat juga harus berperan dalam pengawasan tersebut. Masyarakat dapat memantau, baik secara langsung maupun tidak langsung, proses berjalannya suatu demokrasi/pemilu. Hasil kajian saat ini menunjukkan bahwa ada beberapa penyebab terjadinya golput pada Pilkada 2018 lalu, yaitu: 1) Faktor internal yang meliputi faktor teknis dan faktor pekerjaan, 2). Faktor eksternal yang meliputi faktor administrasi, dan faktor politik. Ada juga solusi untuk mengurangi angka golput pada pemilu berikutnya dengan melonggarkan aturan bagi pemilih untuk dapat memilih, memperbaiki sistem pendataan dan pendaftaran pemilih sehingga memiliki pandangan yang lebih segar (membutuhkan per- 
sonel dan dukungan anggaran yang memadai), mengubah hak untuk memilih menjadi kewajiban untuk memilih. Sistem pemilu harus sangat mudah dipahami oleh pemilih (misalnya, prosedur pemungutan suara yang mudah, desain surat suara yang sederhana). Untuk solusi tersebut, perlu melibatkan kelompok-kelompok strategis, seperti pemilih pemula, umat beragama, perempuan, penyandang disabilitas, dan kelompok marjinal.

Kata kunci: Komunikasi, Pemilu, Golput

\section{Pendahuluan}

Pemilihan Umum (Pemilu) menurut beberapa kalangan merupakan sebuah agenda rutinitas yang menghabiskan banyak anggaran. Anggapan tersebut berdasarkan pada pelaksanaan pemilu yang sudah pernah dilaksanakan oleh bangsa Indonesia belum mendapatkan hasil yang sesuai dengan keinginan masyarakat. Bahkan masyarakat berasumsi bahwa pelaksaan pemilu dari tahun 1955 sampai 2014 ini belum bisa menghasilkan pemerintahan yang sesuai diamanatkan dalam UUD 1945 yaitu mengenai tujuan Negara. Tujuan Negara yang dimaksud adalah mencapai kesejahteraan masyakat.

Pelaksanaan pemilu sebagai simbol pesta demokrasi terus menyisakan berbagai permasalahan yang hadir setelah dilaksanakan, salah satunya adalah permasalahan sengketa hasil pemilu, baik itu pemilu legislative maupun pemilu kepala daerah. Dari masalah ini akhirnya menimbulkan adanya like and dislike diantara pendukung maupun masyarakat, yang kemudian menciptakan ketidakharmonisan ditengah-tengah masyarakat. Selain itu, pemilu dianggap sebagai sarana untuk melakukan tindak pidana korupsi, karena pemilu di Negara kita masih sarat dengan adanya money politic. Memang berbagai persepsi tersebut merupakan opini yang muncul di masyarakat. Padahal secara kelembagaan Negara permasalahan pemilu yaitu mengenai cost and benefit. Maksudnya adalah bagaimana pemerintah bisa melaksanakan pemilu dengan anggaran yang sedikit tapi mampu menghasilkan output pemilu yang bagus.

Banyak pakar politik menilai bahwa ada banyak solusi untuk menghemat anggaran Negara dalam pelaksanaan pemilu, salah satunya adalah pemilu serentak yang diwacanakan dilaksanakan pada tahun 2019. Pemilu Serentak 2019 adalah penyelenggaraan pemilu legislatif dengan eksekutif yang dilakukan secara bersamaan. Keputusan ini dikeluarkan melalui Keputusan Mahkamah Konstitusi (MK) No 14/PUU-11/2013 Tentang Pemilihan Umum Serentak. Keputusan Hukum ini dihasilkan dari proses pengabulan usulan menguji materi Undang-Undang No. 42 Tahum 2008 tentang Pemilihan Presiden dan Wakil Presiden yang diajukan oleh Pakar Komunikasi Politik Universitas Indonesia Dr. Effendi Gazali bersama Koalisi Masyarakat untuk Pemilu Serentak. Pada putusan tersebut, MK berdasarkan pertimbangan, bahwa penyelenggaraan Pemilu dua kali, yaitu Pemilu Legislatif dan Pemilu Presiden yang diselenggarakan secara terpisah bertentangan dengan UUD 
1945, dimana pasal 22E menyebutkan bahwa pemilu secara berkala, 5 tahun sekali dilakukan untuk memilih anggota DPR, DPR, DPRD, Presiden dan Wakil Presiden.

Berganti pemimpin, berganti juga corak sistem pemerintahannya. Konsekuensi dari berubahnya sistem Pemerintahan adalah berubahnya fungsi dan hubungan lembaga-lembaga tinggi negara, khususnya antara Eksekutif dan Legislatif. Pemisahan kekuasaan antara lembaga eksekutif dan lembaga legislative atau yang lebih dikenal dengan teori trias politica, bagi beberapa pihak cenderung menimbulkan polarisasi dan instabilitas politik, karenanya tidak cocok dipraktekan dinegara-negara yang baru memasuki transisi demokrasi, salah satunya di Indonesia.

Tingkat partisipasi pemilih di Kabupaten Jember pada Pemilihan Gubernur Jawa Timur 27 Juni 2018 terendah dari 38 kabupaten/kota yang berada di wilayah Jawa Timur. Hasil hitung cepat yang dilakukan KPU Jember memperlihatkan jumlah pemilih yang terdaftar dalam Daftar Pemilih Tetap (DPT) Jember sebesar 1.821.846 pemilih, sedangkan yang menggunakan hak pilihnya sejumlah 981.923 pemilih atau hanya $53.9 \%$.

\section{Kajian Teori \\ Komunikasi}

Untuk memahami pengertian komunikasi tersebut sehingga dapat dilancarkan secara efektif dalam Effendy bahwa para peminat komunikasi sering kali mengutip paradigma yang dikemukakan oleh Harold Lasswell dalam karyanya, The Structure and Function of Communication in Society. ${ }^{1}$ Lasswell mengatakan bahwa cara yang baik untuk untuk menjelaskan komunikasi ialah dengan menjawab pertanyaan sebagai berikut: Who Says What In Which Channel To Whom With What Effect?

Jadi berdasarkan paradigma Lasswell tersebut, secara sederhana proses komunikasi adalah pihak komunikator membentuk (encode) pesan dan menyampaikannya melalui suatu saluran tertentu kepada pihak penerima yang menimbulkan efek tertentu.

\section{Strategi Komunikasi}

a. Pengertian Strategi Komunikasi

Menurut Onong Uchjana Effendi dalam buku berjudul "Dimensi-dimensi Komunikasi” menyatakan bahwa : “.... strategi komunikasi merupakan panduan dari perencanaan komunikasi (communication planning) dan manajemen (communications management) untuk mencapai suatu tujuan. Untuk mencapai tujuan tersebut strategi komunikasi harus dapat menunjukkan bagaimana operasionalnya secara taktis harus dilakukan, dalam arti kata bahwa pendekatan (approach) bisa

${ }^{1}$ Effendy, Onong Uchjana. 2015. Ilmu Komunikasi Teori dan Praktek Komunikasi. (Bandung: PT. Citra Aditia Bakti, 2015). 10 


\section{berbeda sewaktu-waktu tergantung dari situasi dan kondisi". ${ }^{2}$}

Selanjutnya menurut Onong Uchjana Effendi bahwa strategi komunikasi terdiri dari dua aspek, yaitu :

a) Secara makro (Planned multi-media strategy)

b) Secara mikro (single communication medium strategy)

Kedua aspek tersebut mempunyai fungsi ganda, yaitu :Menyebarluaskan pesan komunikasi yang bersifat informatif, persuasif dan instruktif secara sistematis kepada sasaran untuk memperoleh hasil yang optimal.Menjembatani "cultural gap" , misalnya suatu program yang berasal dari suatu produk kebudayaan lain yang dianggap baik untuk diterapkan dan dijadikan milik kebudayaan sendiri sangat tergantung bagaimana strategi mengemas informasi itu dalam dikomunikasiknnya. ${ }^{3}$

Sedangkan menurut Anwar Arifin dalam buku 'Strategi Komunikasi' menyatakan bahwa : Sesungguhnya suatu strategi adalah keseluruhan keputusan kondisional tentang tindakan yang akan dijalankan, guna mencapai tujuan. Jadi merumuskan strategi komunikasi, berarti memperhitungkan kondisi dan situasi (ruang dan waktu) yang dihadapi dan yang akan mungkin dihadapi di masa depan, guna mencapai efektivitas. Dengan strategi komunikasi ini, berarti dapat ditempuh beberapa cara memakai komunikasi secara sadar untuk menciptakan perubahan pada diri khalayak dengan mudah dan cepat. ${ }^{4}$

b. Teori Dalam Strategi Komunikasi

Dalam hal strategi dalam bidang apa pun tentu harus didukung dengan teori. Begitu juga pada strategi komunikasi harus didukung dengan teori, dengan teori merupakan pengetahuan mendasar pengalaman yang sudah diuji kebenarannya. Karena teori merupakan suatu statement (pernyataan) atau suatu konklusi dari beberapa statement yang menghubungkan (mengkorelasikan) suatu statement yang satu dengan statement lainnya.

Jika diuraikan Formula Lasswell tersebut dapat dilihat pada skema yang digambarkan oleh Denis Mc Quail dan Sven Windahl sebagai berikut : Telaah komunikator meliputi analisis hal-hal sebagai berikut :Sejauhmana si komunikator mempunyai percaya diri (self confident). Dikarenakan dalam Komunikasi Interpersonal ciri/karakteristiknya yang pertama dimulai dari diri sendiri maka komunikator harus percaya pada kemampuannya sendiri untuk melakukan relasi Komunikasi Interpersonal.

Cultural Norms Theory, bahwa melalui penyajian yang selektif dan penekanan pada tema tertentu media massa menciptakan kesan-kesan pada khalayak bahwa norma-norma budaya yang sama mengenai topik-topik tertentu dibentuk

\footnotetext{
${ }^{2}$ Effendy, Onong Uchjana, Komunikasi Teori dan Praktek, (Bandung: Remaja, 1981).84

${ }^{3}$ Ibid. 67

4 Arifin, Anwar. Strategi Komunikasi Sebuah Pengantar Ringkas (Bandung: ARMICO,1984).10
} 
dengan cara-cara khusus dengan batas-batas situasi perorangan, yaitu ada tiga :

a) reinforce existing patterns, bahwa pesan komunikasi dapat memperkuat polapola yang sudah ada dan mengarahkan orang-orang untuk peraya bahwa suatu bentuk sosial dipelihara oleh masyarakat.

b) create new shared convictions, bahwa media massa dapat menciptakan keyakinan baru mengenai suatu topik yang dengan topik tersebut khalayak kurang berpengalaman sebelumnya.

c) change existing norms, bahwa media massa dapat merubah norma-norma yang sudah ada dan karenanya dapat merubah tingkah laku orang-orang. ${ }^{5}$

\section{Upaya Mengurangi Angka Golput}

Pemilu disajikan untuk mengetahui keinginan dan kehendak masyarakat tentang apa dan siapa dalam ukuran logika rakyat yang layak untuk memimpin, memberikan perubahan ataupun perbaikan nasib bagi seluruh rakyat dalam suatu negara. Partisipasi menjadi penting guna menentukan dan menilai penguasa. Pada masa orde baru, penguasa bercorak militeristik begitu kuat, kelompok civil society tak berdaya membendung berbagai kebijakan tak populis. Kondisi demikian mendorong sekelompok intelektual yang dikomandoi Arif Budiman untuk menentang ketidak adilan struktural lewat gerakan moral. ${ }^{6}$

Golput juga dimaknai sebagai prilaku apatisme (jenuh) dengan tematema pemilihan. Kejenuhan tersebut disebabkan oleh suatu kondisi psikologis masyarakat yang hampir tiap tahun mengalami pemilu, pilgub, pilkada dan bahkan pilkades. Disisi lain, penyelenggaraan pemilu yang berulang-ulang tak juga memberikan banyak hal terkait perbaikan nasib bagi masyarakat. Pada titik tertentu rasa jenuh tersebut sampai pada rasa tak peduli apakah dirinya masuk dalam daftar pemilih tetap atau tidak sama sekali. Dengan kata lain, golput merupakan akumulasi sikap jenuh masyarakat terhadap seputar pemilu. baik janji politik, money politik dan kekerasan politik dan kondisi-kondisi pasca reformasi yang tak kunjung membaik.

Dari beberapa pengertian di atas, dapatlah disimpulkan bahwa golput adalah pilihan tidak memilih sebagai bentuk akumulasi rasa jenuh (apatis) masyarakat yang nyaris setiap tahun mengalami pemilihan kepala daerah, golput juga sebagai reaksi atau protes atas pemerintahan dan partai-partai politik yang tidak menghiraukan suara rakyat, perlawanan terhadap belum membaiknya taraf kehidupan masyarakat baik secara ekonomi, politik, hukum dan budaya. Golput merupakan respon atas ketidakmampuan partai atau penguasa dalam menjalankan fungsinya sebagai wakil rakyat yang telah menerima mandat.

a) Latar Belakang Timbulnya Golput

Golput (non-voting behaviour) dalam konteks politik Indonesia memiliki

\footnotetext{
${ }^{5}$ Effendy, Onong Uchjana, Komunikasi Teori dan Praktek, (Bandung: Remaja, 1981).69

${ }^{6}$ Ramlan Subakti, Memahami Ilmu Politik, (Jakarta: PT. Gramedia.1999).176
} 
rentang sejarah yang panjang. Sebagaimna disebutkan di atas, pemerintahan Orde Baru ingin merombak sistem kepartaian di Indonesia, dengan mendasarkan pada konsep Ali Murtopo. Inti dari konsep tersebut adalah gagasan "massa mengambang". Konsep bahwa rakyat akan menyibukkan dirinya dalam usaha-usaha pembangunan mengingatkan sesorang pada gagasan "perkakas yang bersuara" yang biasa terdapat dalam masyarakat perbudakan. Rakyat pedesaan, yang merupakan mayoritas penduduk pada tahun 1965-75, benar-benar diarahkan hanya untuk bekerja, berproduksi dan tak memiliki kesempatan berperan dalam ranah politik.

Pada giliranya konsep tersebut membawa petaka besar bagi perjalanan demokrasi Indonesia. Upaya perampingan konstestan pemilu lewat sistim try kepartaian ini nyatanya mengubah dari partisipasi politik aktif ke partisipasi politik pasif. Akibatnya menguatnya posisi negara dan rakyat terus tersubordinasi. Kenyatan ini bentuk dari intervensi negara dan hilangnya kebebasan rakyat ditengah penegakan demokrasi.

b) Teori Perilaku Golput

Secara garis besar perilaku golput (voting behavior) dapat didekati dari dua model, yaitu:

\section{Pendekatan Sosiologi}

Pendekatan sosiologi ini disebut juga madhab Columbia (The Columbia School of Electoral Behavior). Pendekatan ini menjelaskan karakteristik sosial dan pengelompokan-pengelompokan sosial mempunyai pengaruh yang cukup signifikan dalam menentukan perilaku memilih seseorang. Pengelompokan seperti umur (tua-muda), jenis kelamin (lakiperempuan), agama dan semacamnya diyakini punya peranan penting mengkonstruksi pola pikir pemilih. Pemahaman akan ikatan-ikatan keagamaan, profesi, kelompok bisnis, keluarga dan kelompok informal merupakan sesuatu yang sangatvital.

Dean Jaros menguatkan bahwa perilaku politik seseorang berhubungan erat dalam satuan keanggotaan kelompok tertentu Dean Jaros ${ }^{7}$ Gerad Pomper lebih tegas menjelaskan pengaruh pengelompokan sosial dalam kaitanya dengan perilaku golput. Baginya perilaku golput dapat diletakkan dalam bingkai predisposisi sosialekonomi keluarga pemilih dan predisposisi sosial-ekonomi pemilih sendiri. Keduanya mempunyai hubungan signifikan dengan perilaku memilih seseorang. Maksudnya kondisi ayah dan ibu pemilih akan berpengaruh pada perilaku politik anak, termasuk dalam memilih agama yang dianut, tempat tinggal, dan kelas sosial. 8

${ }^{7}$ Dean Jaros, et al, Political Behavior, Choice and Pespectives, (New York : St. Martin's Press.1974). 111

${ }^{8}$ Geral Pomper, Voter's Choice, Varietes of American Electoral Behavior, (New York: Dod, Mead Company. 1978 ).196

204 | Ferdian Ardani Putra, Ahmad Fauzi 


\section{Pendekatan Psikologi}

Pendekatan psikologi berkembang di Michigan yang dipelopori oleh August Cambell. Ketidak puasan pendekatan sosiologi melahirkan pendekatan psikologi. Konsep yang dikembangkan adalah konsep sosialisasi dan sikap-dalam melihat perilaku memilih. Aktivitas memilih sangat ditentukan oleh kekuatan sosialisasi yang diterima oleh anak sejak masa kecil. Oleh karena itu, dalam pendekatan psikologi ditekankan pada tiga aspek utama, yaitu: ikatan emosional pada suatu partai politik tertentu, orientasi isu-isu dan orientasi pada kandidat. ${ }^{9}$

Bagi psikolog, sikap merupakan refleksi fungsi kepentingan. Penilaian terhadap suatu obyek diberikan berdasarkan motivasi, minat dan kepentingan orang tersebut. Sikap juga berfungsi sebagai penyesuian diri. Individu bersikap tertentu merupakan akibat dari keinginan orang tersebut untuk sama ataupun beda dengan orang lain, termasuk panutannya. Sikap juga berfungsi untuk mengatasi konflik internal, seperti idealisasi, rasionalisasi dan indentifikasi. Sikap bukanlah suatu hal yang langsung jadi, terdapat proses panjang yang membentuknya baik melalui informasi, maupun pendisiplinan. Maka sikap seseorang dibentuk sejak kecil hingga dewasa, sikap politikpun ditentukan pada saat dewasa ketika mengahadapi situasi di luar keluarga yang itu dipengaruhi oleh kelompok acuan, organisasi, asosiasi dan partai politik ${ }^{10}$ Sosialisasi membentuk ikatan psikologi yang begitu kuat antara seseorang dengan organisasi kemasyarakatan atau partai politik yang berupa simpati. Selanjutnya ikatan itu mewujud dalam bentuk identifikasi.

\section{Faktor Kepercayaan}

Politik Ketidak aktifan pemilih (golput) merupakan bentuk ketidak percayaan pada sistem politik. Maka golput merupakan tindakan pada apa yang disebut tidak mendukung sistem politik yang sedang dijalankan.

\section{Pembahasan}

Pemilu disajikan untuk mengetahui keinginan dan kehendak masyarakat tentang apa dan siapa dalam ukuran logika rakyat yang layak untuk memimpin, memberikan perubahan ataupun perbaikan nasib bagi seluruh rakyat dalam suatu negara.1 Partisipasi menjadi penting guna menentukan dan menilai penguasa. Pada masa orde baru, penguasa bercorak militeristik begitu kuat, kelompok civil society tak berdaya membendung berbagai kebijakan tak populis. Kondisi demikian mendorong sekelompok intelektual yang dikomandoi Arif Budiman untuk menentang ketidak adilan struktural lewat gerakan moral. ${ }^{11}$

${ }^{9}$ Richard G. Niemi and Herbet F. Wisberg, Controversies of Voting Behavior, (Washington D.C: A. Devision of Congsional Quarterly Inc.1986).12-13

${ }^{10}$ David Apter, Pengantar Analisa Politik, (Jakarta: LP3ES,1976).262.

${ }^{11}$ Ramlan Subakti, Memahami Ilmu Politik, (Jakarta: PT. Gramedia. 1999).176 
Golongan putih atau disingkat golput adalah istilah politik yang berawal dari gerakan protes dari para mahasiswa dan pemuda untuk memprotes pelaksanaan Pemilu 1971 yang merupakan pemilu pertama di era Orde Baru. Sejak saat itu, gerakan golput kerap terdengar. Ada beberapa faktor terjadinya golput di Kabupaten Jember antara lain:

\section{Penyebab Terjadinya Golput}

\section{a) Faktor Internal}

\section{Faktor Teknis}

Faktor teknis yang penulis maksud adalah adanya kendala yang bersifat teknis yang dialami oleh pemilih sehingga menghalanginya untuk menggunakan hak pilih. Seperti pada saat hari pencoblosan pemilih sedang sakit, pemilih sedang ada kegiatan yang lain serta berbagai hal lainnya yang sifatnya menyangkut pribadi pemilih. Kondisi itulah yang secara teknis membuat pemilih tidak datang ke TPS untuk menggunakan hak pilihnya.

Faktor teknis ini dalam pemahaman dapat di klasifikasikan ke dalam dua hal yaitu teknis mutlak dan teknis yang bisa di tolerir. Teknis mutlak adalah kendala yang serta merta membuat pemilih tidak bisa hadir ke TPS seperti sakit yang membuat pemilih tidak bisa keluar rumah. Sedang berada di luar kota. Kondisi yang seperti yang penulis maksud teknis mutlak. Teknis yang dapat di tolerir adalah permasalahan yang sifatnya sederhana yang melakat pada pribadi pemilih yang mengakibat tidak datang ke TPS.

\section{$>$ Faktor Pekerjaan}

Faktor pekerjaan adalah pekerjaan sehari-hari pemilih. Faktor pekerjaan pemilih ini dalam pemahaman penulis memiliki kontribusi terhadap jumlah orang yang tidak memilih. Data di atas menunjukkan sebagian besar penduduk Indonesia bekerja di sektor informal, dimana penghasilanya sangat terkait dengan intensitasnya bekerja. Banyak dari sektor informal yang baru mendapatkan penghasilan ketika mereka bekerja, tidak bekerja berarti tidak ada penghasilan. Seperti tukang ojek, buruh harian, nelayan, petani harian.

Kemudian ada pekerjaan masyarakat yang mengharuskan mereka untuk meninggal tempat tinggalnya seperti para pelaut, penggali tambang. Kondisi seperti membuat mereka harus tidak memilih, karena faktor lokasi mereka bekerja yang jauh dari TPS. Maka dalam pemahaman penulis faktor pekerjaan cukup singifikan pada pada faktor internal membuat pemilih untuk tidak memilih. Pemilih dalam kondisi seperti ini dihadapkan pada dua pilihan menggunakan hak pilih yang akan mengancam berkurang yang penghasilannya atau pergi bekerja dan tidak memilih.

\section{b) Faktor Eksternal}

Faktor ektenal faktor yang berasal dari luar yang mengakibatkan pemilih tidaknmenggukan hak pilihnya dalam pemilu. Ada tiga yang masuk pada kategori ini 
menurut pemilih yaitu aspek administratif, sosialisasi dan politik.

\section{$>$ Faktor Administratif}

Faktor adminisistratif adalah faktor yang berkaitan dengan aspek adminstrasi yang mengakibatkan pemilih tidak bisa menggunakan hak pilihnya. Diantaranya tidak terdata sebagai pemilih, tidak mendapatkan kartu pemilihan tidak memiliki identitas kependudukan (KTP). Hal-hal administratif seperti inilah yang membuat pemilih tidak bisa ikut dalam pemilihan. Pemilih tidak akan bisa menggunakan hak pilih jika tidak terdaftar sebagai pemilih. Kasus pemilu legislatif 2014 adalah buktinya banyaknya masyarakat Indonesia yang tidak bisa ikut dalam pemilu karena tidak terdaftar sebagai pemilih. Jika kondisi yang seperti ini terjadi maka secara otomatis masyarakat akan tergabung kedalam kategori golput.

Golput yang diakibat oleh faktor administratif ini bisa diminimalisir jika para petugas pendata pemilih melakukan pendataan secara benar dan maksimal untuk mendatangi rumah-rumah pemilih. Selain itu dituntut inisiatif masyarakat untuk mendatangi petugas pendataan untuk mendaftarkan diri sebagai pemilih. Langkah berikutnya DPS (Daftar Pemilih Sementara) harus tempel di tempat-tempat strategis agar bisa dibaca oleh masyarakat. Masyarakat juga harus berinisiatif melacak namanya di DPS, jika belum terdaftar segara melopor ke pengrus RT atau petugas pendataan. Langkah berikut untuk menimalisir terjadi golput karen aspek adminitrasi adalah dengan memanfaatkan data kependudukan berbasis IT. Upaya elektoronik Kartu Tanda Penduduk (E KTP) yang dilakukan pemerintahan sekarang dalam pandangan penulis sangat efektif dalam menimalisir golput administratif.

\section{Faktor Politik}

Faktor politik adalah alasan atau penyebab yang ditimbulkan oleh aspek politik masyarakat tidak mau memilih. Seperti ketidak percaya dengan partai, tak punya pilihan dari kandidat yang tersedia atau tak percaya bahwa pileg/pilkada akan membawa perubahan dan perbaikan. Kondisi inilah yang mendorong masyarakat untuk tidak menggunakan hak pilihnya.

Stigma politik itu kotor, jahat, menghalalkan segala cara dan lain sebagainya memperburuk kepercayaan masyarakat terhadap politik sehingga membuat masyarakat enggan untuk menggunakan hak pilih. Stigma ini terbentuk karena tabiat sebagian politisi yang masuk pada kategori politik instan. Politik dimana baru mendekati masyarakat ketika akan ada agenda politik seperti pemilu. Maka kondisi ini meruntuhkan kepercayaan masyarakat pada politisi. Faktor lain adalah para politisi yang tidak mengakar, politisi yang dekat dan memperjuangkan aspirasi rakyat. Sebagian politisi lebih dekat dengan para petinggi partai, dengan pemegang kekuasaan. Mereka lebih menngantungkan diri pada pemimpinnya di bandingkan mendekatkan diri dengan konstituen atau pemilihnya.

Kondisi lain adalah tingkah laku politisi yang banyak berkonflik mulai kon- 
flik internal partai dalam mendapatkan jabatan strategis di partai, kemudian konflik dengan politisi lain yang berbeda partai. Konflik seperti ini menimbulkan anti pati masyarakat terhadap partai politik. Idealnya konflik yang di tampilkan para politisi seharusnya tetap mengedepankan etika politik (fatsoen).

Politik pragamatis yang semakin menguat, baik dikalangan politisi maupun di sebagian masyarakat. Para politisi hanya mencari keuntungan sesaat dengan cara mendapatkan suara rakyat. Sedangan sebagian masyarakat kita, politik dengan melakukan transaksi semakin menjadi-jadi. Baru mau mendukung, memilih jika ada mendapatkan keutungan materi, maka muncul ungkapan kalau tidak sekarang kapan lagi, kalau sudah jadi/terpilih mereka akan lupa janji. Kondisi-kondisi yang seperti penulis uraikan ini yang secara politik memengaruhi masyarakat untuk menggunakan hak pilihnya. Sebagian Masyarakat semakin tidak yakin dengan politisi. Harus diakui tidak semua politisi seperti ini, masih banyak politisi yang baik, namun mereka yang baik tenggelam dikalahkan politisi yang tidak baik.

\section{Upaya mengurangi angka golput untuk pemilu selanjutnya}

Golput di Indonesia terutama di kabupaten Jember sudah tidak dapat dibendung lagi saat pemilihan Gubernur dan Wakil Gubernur Tahun 2018 karena hal ini telah terjadi dan telah melekat didalam diri bagi mereka yang sering melakukan golput namun sebagai pemerintah maupun dari pihak masyrakat yang harus samasama berkerjasama dalam mengatasi hal yang sebenarnya dianggap hal sepele ini.

Seperti yang kita ketahui bahwa banyaknya angka golput di Indonesia merupakan kesalahan dari berbagai pihak.Kita tidak mugkin menghilangkan begitu saja angka golput namun masyarakat danpemeritah harus menakan angka golput. Untuk menekan angka golput, Lamhir berharap agar Komisi Pemilihan Umum dan partai politik lebih giat lagi melakukan sosialisasi dan memberikan pemahaman kepada masyarakat bahwa memilih itu merupakan kewajiban yang harus dilaksanakan oleh semua warga Negara. KPU dan partai harus bisa menyakinkan masyarakat bahwa ketika menjadi golput bisa dikategorikan sebagai orang yang tidak peduli terhadap Negara yang telah dibentuk oleh para pendahulu dengan mengorbankan jiwa dan raganya Rendahnya partisipasi politik masyarakat Jember disebabkan oleh banyak kasus yang menguraikan partai politik, kurangnya potensi tokoh partai politik, dan kemunduran citra partai. Penelitian bertujuan untuk menemukan upaya sosialisasi Pemilu 2019 dari Komisi Pemilihan Umum untuk mengurangi tingkat abstain dan bagaimana media membentuk opini publik untuk mengurangi jumlah orang yang tidak berprestasi.

KPU merekrut agen sosialisasi pada tahun 2019 memasang poster dan spanduk, melakukan kegiatan bersama dengan agen sosialisasi dan mengingkatkan jumlah TPS. KPU menyebar informasi tersebut ke media massa untuk dipublikasikan. Tujuannya adalah untuk melibatkan masyarakat dan berkontribusi pada keberhasilan pemilihan. Media massa elektronik perlu membuat program yang membantu sosialisassi pemilihan, misalnya berdiskusi terbuka dari semua pihak yang berpartisipasi dalam pemilihan dalam slot khusus yang diberikan oleh pemerintah, kemudian mereka menjelaskan program dan komitmen pro-rakyat mereka. 
Solusi mengatasi golput antara lain:

a. Permudah aturan bagi pemilih untuk dapat menggunakan hak pilih.

b. Perbaiki sistem pendataan dan pendaftaran pemilih sehingga menjadi lebih muda (perlu dukungan personil dan anggaran yang memadai).

c. Mengubah hak memilih menjadi kewajiban memilih.

d. Sistem pemilu yang digunakan harus sangat mudah dipahami oleh pemilih (misalnya, tata cara memberikan suara yang mudah, design surat suara yang sederhana).

Dari bagian diatas perlu adanya pelibatkan Kelompok-kelompok strategis, seperti pemilih pemula, kaum beragama, perempuan, penyandang disabilitas dan kaum marginal.

\section{Kesimpulan}

Penilaian untuk keberhasilan pemilu, dapat menggunakan ukuran secara normatif yakni pemilu berjalan lancar, dan output atau luaran yang dihasilkan sesuai dengan harapan rakyat. Masalah pendaftaran pemilu merupakan suatu masalah yang cukup besar. Di sisi lain, output pemilu perlu mengusung figur-figur baru agar Pemilu tersebut dapat berkualitas.

Salah satu keberhasilan pemilu dapat dilihat dari tingkat partisipasi pemilihnya, selain parameter-parameter lainnya seperti kemampuan mengelola konflik dan terpilihnya individu yang kredibel. Pemilihan umum jangan hanya dilihat sebagai sebuah aktifitas administratif belaka, namun lebih menekankan pada makna substansinya.

Pada konteks ini, pemilihan harus didesain agar dapat menjadi sebuah pesta rakyat yang menghibur (electiontainment). Produk sosialisasi dan pendidikan pemilih harus dikemas dalam bentuk yang menghibur, ringan, dan lebih dekat dengan kultur masyarakat. Model sosialisasi seperti ini akan melibatkan industri hiburan massal seperti olah raga, budaya, maupun musik.

\section{Daftar Pustaka}

Ahadiyanto, Nuzul. Hubungan Dimensi KepribadianThe Big Five Personality Dengan Tingkat Kesejahteraan Psikologis Narapidana. Jurnal Al-Hikmah, 2020, 18.1: 117-130.

Al Ahsani, Nasirudin. Kepemimpinan Perempuan Pada Masyarakat dalam Perspektif Sa î̀d Ramaḍān Al-Būṭī (Telaah Hadis Misoginis). Jurnal Al-Hikmah, 2020, 18.1: 57-74.

Alwi, Muhammad Muhib. Pemberdayaan Ekonomi Masyarakat Berbasis Masjid di Tengah Pandemi Covid-19. Jurnal Al-Hikmah, 2020, 18.1: 99-116.

Arifin, Anwar. 1984, Strategi Komunikasi Sebuah Pengantar Ringkas, Bandung: ARMICO,

Cangara, Hafidz,2005, Pengantar Ilmu Komunikasi, Jakarta: PT Raja Grafindo Persada.

David Apter, 1976, Pengantar Analisa Politik, Jakarta: LP3ES

Dean Jaros, et al, 1974, Political Behavior, Choice and Pespectives, New York : St. Martin's Press. 
Dawud, Mochammad. Menerapkan Manajemen Strategi Penyiaran untuk Penyiaran Dakwah. Jurnal Al-Hikmah, 2019, 17.1: 109-140.

Dawud, Mochammad; Choliq, Abdul. Manajemen Strategi Ala NU Tv 9 Menghadapi Televisi Swasta Lokal di Surabaya. Jurnal Al-Hikmah, 2020, 18.1: 75-98.

Elanda, Yelly. Komodifikasi Agama pada Perumahan Syariah di Surabaya. Jurnal Al-Hikmah, 2019, 17.1: 41-62.

Effendy, Onong Uchjana, 1981, Komunikasi Teori dan Praktek, Bandung: Remaja Pengantar Ilmu Komunikasi, Jakarta: Rosdakarya Grasindo.

, Onong Uchjana. 2015. Ilmu Komunikasi Teori dan Praktek Komunikasi. Bandung: PT. Citra Aditia Bakti

Fauzi, Ahmad. Problematika Dakwah di Tengah Pandemi Covid 19 Mewabah. Jurnal Al-Hikmah, 2020, 18.1: 27-36.

Geral Pomper, Voter's Choice : 1978, Varietes of American Electoral Behavior, New York: Dod, Mead Company.

Hadi, H. Sofyan. Manajemen Strategi Dakwah di Era Kontemporer. Jurnal AlHikmah, 2019, 17.1: 79-90.

Isfironi, Mohammad. Kota Santri, Bumi Shalawat Nariyah dan Bule-Dhika. Jurnal Al-Hikmah, 2019, 17.1: 1-20.

Jannah, Hasanatul. Pondok Pesantren Sebagai Pusat Otoritas Ulama Madura. Jurnal Al-Hikmah, 2019, 17.1: 91-108.

Littlejohn, Stephen W. 2001. Theories of Human Communication. USA: Wadsworth Publishing.

Materi dalam Seminar Nasional "Evaluasi Pemilihan Gubernur Sacara Langsung”, yang diadakan oleh Masyarakat Ilmu Pemerintahan (MIPI) Provinsi Kepulauan Riau, pada tanggal 27 Juni 2011 di TanjungpinangKepulauan Riau.

Mulyana, Deddy. 2001. Ilmu Komunikasi: Suatu Pengantar. Bandung: Rosda.

Ramlan Subakti, 1999, Memahami Ilmu Politik, Jakarta: PT. Gramedia.

Richard G. Niemi and Herbet F. Wisberg, 1984, Controversies of Voting Behavior, Washington D.C: A. Devision of Congsional Quarterly Inc.

Ruben, Brent D,Stewart, Lea P, 2005, Communication and Human Behaviour,USA:Alyn and Bacon.

Sendjaja, Sasa Djuarsa, 1994, Pengantar Komunikasi Jakarta: Universitas Terbuka.

Setiawan, Eko. Makna Nilai Filosofi Wayang Kulit Sebagai Media Dakwah. Jurnal Al-Hikmah, 2020, 18.1: 37-56.

Soebagio, Implikasi Golongan Putih Terhadap Pembangunan Demokratisasi di Indonesia, dalam Jurnal Makara: Sosial Humaniora, Vol 12 No 2, Desember 2008.

Wazis, Kun. Perlawanan Ahli Hadis terhadap Gerakan Radikalisme Dalam Konstruksi Media Online. Jurnal Al-Hikmah, 2019, 17.1: 20-40. 